NBER WORKING PAPER SERIES

\author{
THE GOVERNMENT AS VENTURE \\ CAPITALIST: THE LONG-RUN IMPACT \\ OF THE SBIR PROGRAM
}

Josh Lerner

Working Paper 5753

NATIONAL BUREAU OF ECONOMIC RESEARCH

1050 Massachusetts Avenue

Cambridge, MA 02138

September 1996

I thank Fran Featherston, Lowell Mininger, and Mark Nadel of the U.S. General Accounting Office and Jesse Reyes of Venture Economics for access to data; Horace Crouch and Robert Wrenn of the U.S. Department of Defense for assistance in arranging interviews with awardees; and Lewis Branscomb, Ken Flamm, Paul Gompers, Adam Jaffe, Scott Wallsten, and seminar participants at the NBER Science and Technology Policy Meeting and Harvard Business School for helpful comments. Chris Allen, Mannie Liu, and Kathleen Ryan provided research assistance. I thank the Center for Science and International Affairs at the Kennedy School of Government and the Division of Research at Harvard Business School for financial support. This paper is part of NBER's research program in Productivity. Any opinions expressed are those of the author and not those of the National Bureau of Economic Research.

(C) 1996 by Josh Lerner. All rights reserved. Short sections of text, not to exceed two paragraphs, may be quoted without explicit permission provided that full credit, including $(\mathbb{O}$ notice, is given to the source. 


\title{
THE GOVERNMENT AS VENTURE \\ CAPITALIST: THE LONG-RUN IMPACT \\ OF THE SBIR PROGRAM
}

\begin{abstract}
Public programs to provide early-stage financing to firms, particularly high-technology companies, have become commonplace in the United States and abroad. The long-run effectiveness of these programs, however, has attracted little empirical scrutiny. This paper examines the impact of the largest U.S. public venture capital initiative, the Small Business Innovation Research (SBIR) program, which has provided over \$6 billion to small high-technology firms between 1983 and 1995. Using a unique database of awardees compiled by the U.S. General Accounting Office, I show that SBIR awardees grew significantly faster than a matched set of firms over a ten-year period. The positive effects of SBIR awards were confined to firms based in zip codes with substantial venture capital activity. The findings are consistent with both the corporate finance literature on capital constraints and the growth literature on the importance of localization effects.
\end{abstract}

Josh Lerner

Graduate School of Business Administration

Morgan Hall

Harvard University

Soldiers Field

Boston, MA 02163

and NBER

jlerner@hbs.edu 


\section{Introduction}

The federal government has played an active role in financing new firms, particularly in high-technology industries, since the Soviet Union's launch of the Sputnik satellite. In recent years, European and Asian nations and many U.S. states have adopted similar initiatives. While these programs' precise structures have differed, the efforts have been predicated on two shared assumptions: (i) that the private sector provides insufficient capital to new firms, and (ii) that the government can identify firms where investments will ultimately yield high social and/or private returns. 'These claims have, however, received little scrutiny by economists. ${ }^{2}$

\footnotetext{
${ }^{1}$ It is striking to note the similarities between, for instance, the statement of Senator John Sparkman [1958] upon the passage of the Small Business Investment Act and the recent testimony of Dr. Mary Good, Under Secretary for Technology at the U.S. Department of Commerce [1995]. The rationales for such programs are discussed in depth in U.S. Congressional Budget Office [1985].

${ }^{2}$ While both government agencies and academic economists have sought repeatedly to assess the efficacy of federal programs to aid technology-intensive industries, they have tended to focus on different questions. Most federal evaluations of these programs have consisted of case studies and surveys of the commercial activity directly attributable to the awards. Examples of such evaluations of the SBIR program include Myers, Stern, and Rorke [1983], Price, Waterhouse [1985], and U.S. General Accounting Office [1987a, 1989, 1992]. Surveys of direct commercial impacts are subject to several biases. For instance, in the case of the SBIR program, small business advocates conducted a protracted lobbying campaign to expand the program. Executives active in this effort may have overstated the benefits from the awards. At the same time, some firms had reasons to downplay the commercial benefits of the program. During the early 1990 s, a number of pharmaceutical and biotechnology companies that developed research originally funded by the National Institutes of Health were intensely scrutinized. Firms that received spectacular commercial benefits from the SBIR program may have been reluctant to acknowledge them, lest they attract unwelcome attention from reporters and politicians. Finally, because many firms pursued SBIR projects closely related to their core technologies, determining the direct impact of an SBIR award may have been difficult. Studies of federal technology programs by academic economists, beginning with Levy and Terleckyj [1983], have tended to focus on the short-run effects of these efforts. In particular, they ask whether federal funds substitute for or stimulate private R\&D spending. For instance, Irwin and Klenow [1994] show that semiconductor manufacturers substantially reduced their own R\&D spending while participating in the Sematech
} 
The neglect of these questions is unfortunate. While the sums of money involved are modest relative to public expenditures on defense procurement or retiree benefits, these programssummarized in Table 1 - are very substantial when compared to contemporaneous private investments in new firms. For instance, the Small Business Investment Company (SBIC) program led to the provision of more than $\$ 3$ billion to young firms between 1958 and 1969 , more than three times the total private venture capital investment during these years (Noone and Rubel [1970]). In 1995, the Small Business Innovation Research (SBIR) program provided almost $\$ 900$ million to young technology-intensive firms. This was about equal to the annual rate of early-stage investments by venture capitalists in recent years (Venture Economics [1996], U.S. Small Business Administration [1996]). Some of America's most dynamic technology companies received support through the SBIC and SBIR programs while still private entities, including Apple Computer, Chiron, Compaq, Federal Express, and Intel. Public venture capital programs have also had a significant impact overseas: for instance, these programs have accounted for more than one-half of the recent investments in new German technology-intensivefirms (Wupperfeld [1992]).

The recent economic literature suggests reasons to be both optimistic and skeptical about the efficacy of public venture programs. On the positive side, a growing body of writing suggests that new firms, especially technology-intensive ones, may be receiving insufficient capital. The literature on capital constraints (reviewed in Hubbard [1996]) documents that an inability to obtain external financing limits many forms of business investment. Particularly relevant are works by

consortium. Wallsten [1996] shows that the subset of SBIR awardees that were publicly traded reduced their own spending on $R \& D$ in the years immediately following the award. 
Hall [1992], Hao and Jaffe [1993], and Himmelberg and Petersen [1994]. These show that capital constraints appear to limit research-and-developmentexpenditures, especially in smaller firms. It might be thought that these effects would have been particularly strong during the 1970 s and early 1980 s, when the venture capital pool was relatively modest in size. As the first panel of Table 2 reports, the pool of venture capital funds has grown dramatically in recent years. This has been largely due to the relaxation of the regulations and informal curbs that precluded many pension funds from investing in this asset class (Fenn, Liang, and Prowse [1995]). The capital constraints literature suggests that public awards to high-technology firms should be associated with significant growth, as firms pursue value-creating projects that they would otherwise be unable to finance. ${ }^{3}$

On the opposing side, the corporate finance literature highlights the importance of private mechanisms to finance young, high-growth firms. The dominant form of financing is venture capital, which accounts for about two-thirds of the external equity financing raised from privatesector sources by privately held technology-intensive businesses (Freear and Wetzel [1990]). Venture investors frequently disburse funds in stages. Managers of these venture-backed firms are forced to repeatedly return to their financiers for additional capital, in order to ensure that the money is not squandered on unprofitable projects. In addition, venture capitalists intensively monitor managers. These investors demand preferred stock with numerous restrictive covenants and representation on the board of directors. (Various aspects of the oversight role played by private equity investors are documented in Gompers [1995], Lerner [1995], and Sahlman [1990];

\footnotetext{
${ }^{3} \mathrm{~A}$ related body of literature documents that investments in $\mathrm{R} \& \mathrm{D}$ yield high private and social rates of return (e.g., Griliches [1986], Mansfield, et al. [1977]). These findings similarly suggest that a higher level of R\&D spending would be desirable.
} 
the theoretical literature is reviewed in Barry [1994].) Government officials are unlikely to have the expertise or resources to effectively monitor entrepreneurs. Consequently, even if an award of public funds to an entrepreneurial firm leads to a short-run expansion in activities, the increase is unlikely to be sustainable.

The academic literature also differs in its predictions of where public grants will have the greatest impact. Venture capital financing is concentrated in particular regions and sectors. The second and third panels of Table 2 document this pattern, showing the distribution of early-stage venture financings by state and Standard Industrial Classification (SIC) code between 1983 and 1985 (the period in which the SBIR awards under study in this paper were made). The concentration of awards in California and Massachusetts, as well as in computer hardware and software sectors, is apparent.

This concentration can be interpreted in two ways. On the one hand, several models argue that institutional investors frequently engage in "herding": making investments that are too similar to one another. These models suggest that a variety of factors - for instance, when performance is assessed on a relative, not an absolute, basis—can lead to investors obtaining poor performance by making too similar investments. (Much of the theoretical literature is reviewed in Devenow and Welch [1996]; Sahlman and Stevenson [1986] present a case study suggesting such behavior by venture capitalists) These models suggest that public investments in sectors and regions less 
heavily supported by venture capitalists might lead to superior returns, because value-creating investments in less popular areas may have been ignored.

On the other hand, recent models of economic growth - building on earlier works by economic geographers - have emphasized powerful reasons why successful high-technology firms may be very concentrated. The literature highlights several factors that lead similar firms to cluster in particular regions, including knowledge spillovers, specialized labor markets, and the presence of critical intermediate good producers. (The theoretical rationales for such effects are summarized in Krugman [1991].) Case studies of the development of high-technology regions (e.g., Saxenian [1994]) have emphasized the importance of intermediaries such as venture capitalists, lawyers, and accountants in facilitating such clustering. If these effects are important, and the supply of venture capital was restricted as discussed above, then we might expect public awards to have particular impact if they were dispersed in the same regions as independent venture capitalists invested.

This analysis assesses the long-run success of firms participating in the largest U.S. public venture capital initiative, the SBIR program. I examined the employment and sales growth of 1135 firms. Approximately half of the sample received one or more awards of approximately one-half million dollars in the first three cycles of the SBIR program; the other half were matching firms constructed to resemble the SBIR awardees as closely as possible. In order to assess the program, I relied heavily on a unique longitudinal data-set of awardees compiled by the U.S. General Accounting Office (GAO). 
One decade later, the SBIR awardees have enjoyed substantially greater employment and sales growth than the matching firms. This superior performance, however, was not universal. The differentials in both employment and sales growth were confined to firms in zip codes that were simultaneously the site of substantial venture capital activity. The SBIR awards appear to have had much less impact on the performance of firms in other regions. The awards contributed both to the growth of firms that were or were not backed by venture capital, and that were or were not in industries heavily financed by venture capital. Some evidence suggests that the positive impact was strongest for firms in areas with many venture investments but in industries not frequently financed by venture capitalists.

While the superior long-run performance of the SBIR awardees is consistent with the presence of capital constraints, it is clearly not the only interpretation. The selection process might lead to the identification of firms with superior long-run prospects The provision of funds itself might make no difference. Alternatively, the selection of a firm for an SBIR award might serve as a favorable signal to potential customers and investors. In other words, the results are consistent with the second claim of the first paragraph of the introduction being true, but the first claim not being true. To address this concern, I employed two sets of matching firms: one set with no participation in the SBIR program; the other which received at least one much smaller, but highly competitive, preliminary SBIR award (termed Phase I awards). If the SBIR awards simply identified superior firms, and the capital provided did not make a difference, I anticipated that the 
long-run success of the Phase I awardees would be consistently greater than that of the nonawardees. The fact that the growth of these two sets of matching firms did not materially differ from each other-both lagged the performance of recipients of the full SBIR awards - suggested that the capital provided was important The results are also robust to controls for the hypothesis that SBIR awardees grew because they established relationships with federal officials or politicians, which led to procurement contracts.

These findings are relevant for several reasons. First, they are consistent with both the corporate finance literature on capital constraints and the growth literature on the importance of localization effects. Second, they provide guidance as to what types of public venture programs are likely to be effective. In particular, they underscore doubts about recent federal efforts to encourage the formation of venture funds investing in economically distressed areas here and abroad. Finally, the findings are relevant to the intensifying policy debate surrounding the SBIR program itself. While the results cannot be unambiguously interpreted, they call into question the arguments of university and medical center administrators (summarized in Mervis [1996]) that the program has not produced any economic benefits.

The plan for the paper is as follows. In Section 2, I review the structure of SBIR awards, and why they may address the financing needs of smaller firms. The third section describes the data set. Section 4 presents the analysis, and the final section concludes the paper. 


\section{The SBIR Program and the Financing of Entrepreneurial Firms}

The Small Business Innovation Development Act, enacted by Congress in July 1982, established the SBIR program. The program-modeled after a pioneering program initiated by the National Science Foundation in 1977—-mandated that all federal agencies spending more than $\$ 100$ million annually on external research set aside a fixed percentage of these funds for awards to small businesses The act required that $1.25 \%$ of all external research be allocated for this program (The set-aside was phased in over five years.) When the program was reauthorized in 1992, Congress increased the size of the set-aside. It will reach its new steady-state level of $2.5 \%$ in 1997 . At this point, total annual funding is projected to be about $\$ 1.1$ billion.

While the eleven federal agencies participating in the program are responsible for selecting awardees, they must conform to the guidelines stipulated by the act and the U.S. Small Business Administration(SBA). Awardees must be independently owned, for-profit firms with less than 500 employees, at least $51 \%$ owned by U.S. citizens or permanent residents. The structure of the awards is also constrained to be similar across agencies. Promising proposals are awarded Phase I awards (originally no more than $\$ 50,000$, today $\$ 100,000$ or smaller), which are intended to allow firms to conduct research to determine the feasibility of their ideas. Approximately one-half of the Phase I awardees are then selected for the more substantial Phase II grants. Phase II awards of at most $\$ 750,000$ (originally, one-half million dollars) are designed to support two years of development work. The funds are transferred to the small firm as a contract or grant. In return for the funding, the company must provide the agency with a report on the technology under 
development. The government receives no equity in the firm and does not have any ownership claim on the intellectual property that the firm develops with these funds. Table 3 displays the annual expenditures on the SBIR program, the percentage set-aside, and the number of Phase II awards.

One of the key rationales for the establishment of the SBIR program was that imperfections existed in the market for the financing of young technology-based firms. These firms are characterized by considerable uncertainty and information asymmetries that permit opportunistic behavior by entrepreneurs. As discussed above, the bulk of the equity invested in these firms comes from venture capitalists, who have developed a variety of mechanisms to limit such behaviors.

But venture capital has important limitations. Venture funds only back a tiny fraction of the technology-oriented businesses begun each year: of those firms that submit business plans to venture organizations, historically only $1 \%$ have been funded (Fenn, Liang, and Prowse [1995]). While this may partially reflect the mixed quality of these proposals, it may also reflect regulatory constraints on pension funds that have until recently limited the size of the venture capital pool. Private pension funds were essentially prohibited from venture investments by the U.S. Department of Labor until 1978. Even after this policy shift, private pensions did not invest in venture funds in significant numbers until the mid-1980s. A variety of regulatory and political factors restrained substantial venture investments by public pension funds until the 1990 s. 
Furthermore, the structure of venture investments is inappropriate for many young firms. Venture funds tend to make quite substantial investments, even in young firms: the mean venture investment in a start-up or early-stage business between 1961 and 1992 was $\$ 1.8$ million (in 1992 dollars) (Gompers [1995]). The substantial size of these investments is largely a consequence of the demands of institutional investors. The typical venture organization raises a fund (structured as a limited partnership) every few years. Because investments in partnerships are often timeconsuming to negotiate and monitor, institutions prefer making relatively large investments in venture funds (typically $\$ 10$ million or more). Furthermore, governance and regulatory considerations lead investors to limit the share of the fund that any one limited partner holds. (The structure of venture partnerships is discussed at length in Gompers and Lerner [1996a].) These pressures lead venture organizations to raise substantial funds. Because each firm in his portfolio must be closely scrutinized, the typical venture capitalist is typically responsible for no more than a dozen investments. Venture organizations are consequently unwilling to invest in very young firms that only require small capital infusions. ${ }^{4}$

\footnotetext{
${ }^{4}$ There are two primary reasons why venture funds do not simply hire more partners if they raise additional capital. First, the supply of venture capitalists is quite inelastic. The effective oversight of young companies requires highly specialized skills that can only be developed with years of experience. A second important factor is the economics of venture partnerships. The typical venture fund receives a substantial share of its compensation from the annual fee, which is typically between $2 \%$ and $3 \%$ of the capital under management. This motivates venture organizations to increase the capital that each partner manages. Recently several industry leaders have explored mechanisms to facilitate investments by institutions in very small venture funds. These partnerships, they hoped, could readily make small investments in start-up firms. These efforts have encountered considerable difficulties (see Vincenti [1996]).
} 
The amount that a firm can raise from the leading alternative source of private equity, individual investors, is usually much less than the minimum financing round that a venture fund will consider providing. Freear and Wetzel [1990] report that median financing round raised by private high-technology firms from individual investors was about $\$ 200,000.82 \%$ of the rounds from individuals were under $\$ 500,000$. Thus, a substantial gap exists between the resources that firms can raise from individual investors and from venture capitalists, which SBIR awards may partially fill.

\section{The Data Set}

Identifying the appropriate metric to assess the long-term effects of the SBIR program is problematic. Ideally, I would measure both the social and private impacts of the program. While case studies of a small number of participants in the SBIR program (along the lines, for instance, of Mansfield, et al. [1977]) might shed some light on the social benefits, such an effort would be impossible for a larger sample. ${ }^{6}$

\footnotetext{
${ }^{5}$ Freear and Wetzel [1990] report that venture capitalists and individual investors were the source of $81 \%$ of the external equity financing raised from non-governmental sources by a sample of 284 privately held high-technology companies.

${ }^{6}$ These analyses were complemented with eleven interviews of Massachusetts firms that had received at least one Phase II award from the Department of Defense. I thank Department's Office of Small and Disadvantaged Business Utilization for their help in identifying these firms and arranging the interviews.
} 
Even determining an appropriate measure of private benefits was difficult. Ideally, I would measure the impact of participating in the program on the firms' valuations. Only $2 \%$ of the SBIR awardees in the first three program cycles, however, were publicly held at the time of their initial Phase I awards. Determining whether participation in the program was associated with an increase in firm value was consequently difficult. I focused instead on two alternatives: the impact of participation in the SBIR program on sales and employment. While neither was a perfect measure of firm value, Paul Gompers and I have shown [1996b] that the valuations assigned to private firms by venture capitalists are highly correlated with these two scale measures.

As a consequence of their status as private firms, almost all SBIR awardees did not need to disclose employment or sales information in filings with the U.S. Securities and Exchange Commission (SEC). Consequently, I relied on a unique database prepared by the GAO. The GAO was mandated in the legislation establishing the SBIR program to periodically evaluate the initiative. In late 1985, the agency generated a sample of 933 firms that received SBIR awards in the first three program cycles from the twelve federal agencies participating in the program at the time. This sample included all firms that had received Phase II awards to that date, as well as a sampling of the firms that had only received the preliminary Phase I awards. ${ }^{7}$

\footnotetext{
${ }^{7}$ At the time that the survey population was selected, not all firms that received Phase I awards in fiscal year 1985 had been selected for Phase II awards. Consequently, some firms that received Phase II awards in the first three program cycles were not included in the survey.
} 
These firms were surveyed by the GAO in early 1986. The survey collected basic demographic data (e.g., the firm's founding date, employment, revenue, and intellectual property holdings), the avenues through which the firm had been financed prior to and after the award, and the organizational changes that occurred after the award (such as a merger or an initial public offering). The survey had an $81 \%$ response rate, which reflected the extensive efforts by GAO, SBA, and agency officials to track down non-responding entrepreneurs and to encourage them to complete the survey. The GAO completed a follow-up survey in mid-1988. $86 \%$ of the original respondents answered this survey, as well as $46 \%$ of the non-respondents to the first survey. In total, 835 firms responded to at least one survey. Of these, 541 received Phase II awards in the first three program cycles, while 294 only received Phase I awards.

In addition to the 294 firms that only received Phase I awards, I constructed a matching sample of 300 firms that received no SBIR funds in the first three program cycles. I sought to select firms that closely resembled the 541 Phase II awardees. I matched firms using Corporate Technology Information Services' Corporate Technology Directory [1996], the most comprehensive directory of U.S. high-technology firms. This directory employs a highly detailed industry classification scheme, which allows quite precise matches. ${ }^{8}$ I recorded the primary industry classification of each Phase II awardee in the 1986 edition of the Corporate Technology Directory, or the first subsequent volume in which the firm was listed. (In all, 74\% of the Phase II awardees were listed.)

\footnotetext{
${ }^{8}$ For instance, while the SIC classification scheme places all software firms in class 7372 , this directory distinguishes between firms that manufacture educational software used to teach typing and for music instruction.
} 
I then pulled a random selection of 300 of these awardees. For each selected firm, I identified in the 1986 Corporate Technology Directory the firm in the same classification with the closest employment level. ${ }^{9}$ I excluded as possible matches firms that were units or subsidiaries of other concerns. I also eliminated firms that had received any Phase I or Phase II awards in the first three program cycles. (These were determined through U.S. Small Business Administration [1986].) If there were no matches within the class, I chose a firm in a related industry: e.g., if there were no appropriate match for a firm classified as a plastic composite laminate manufacturer, I matched the firm to another composite laminate manufacturer. From the listing for each matching firm in the Directory, I collected information on sales, employment, location, and founding date. I determined whether the matching firms had received venture financing using Security Data Company's Venture Intelligence Database. This database provides comprehensive information on venture capital financings, and is described in detail in Lerner [1995].

The samples are summarized in Table 4 and 5. Table 4 describes the construction of the samples; Table 5 compares the Phase II awardees with the matching firms. The firms were similar in most respects. The awardees had slightly larger employment in 1985; the matching firms,

\footnotetext{
${ }^{9}$ It may be questioned why I matched firms exclusively on the basis of their industry and employment, rather than also matching on geographic proximity, or some other attribute. My rationale was that my approach would minimize possible biases due to inter-industry differences that would be very difficult to control for otherwise. (Most studies that control for industry differences use data at the four-digit SIC code level, which is much more crude than the degree of industry matching done here.) Geographic differences, however, could be (and were) addressed through the use of information about venture activity in each zip code.
} 
greater sales. The SBIR awardees were more likely to have received venture financing by the end of 1985 (10\% vs. $7 \%$ for the matching firms) and to be located in either California or Massachusetts (35\% vs. $26 \%)$.

A final step in constructing the sample was determining the employment and sales of the SBIR Phase II awardees and the matching firms at the end of $1995 .^{10}$ For publicly traded firms, I used SEC filings. For private firms, I employed, in order of preference, the 1996 editions of the Corporate Technology Directory, Dun's Marketing Services' Million Dollar Directory [1996], Gale Research's Ward's Business Directory of U.S. Private and Public Companies [1996], National Register Publishing Company's Directory of Leading Private Companies [1996], and a considerable number of state and industry business directories in the collections of Harvard Business School's Baker Library, the Boston Public Library, and the Library of Congress. For firms that I could not find in published directories, I employed several electronic databases: the Company Intelligence and Database America compilations available through LEXIS's COMPANY/USPRIV library, VentureOne's Venture Data System, and the American Business Disk CD-ROM directory.

For firms where I could not ascertain employment and sales, I checked the news stories compiled in LEXIS's NEWS/ALLNEWS library and the Business Dateline, F\&S Index, and Wall

\footnotetext{
${ }^{10}$ In a few cases, firms did not disclose 1985 sales. Furthermore, SBIR awardees were only requested to report ranges for 1985 sales. Consequently, in all cases where firms did not report sales, or where reported sales were in one of the ranges above \$1 million, I ascertained 1985 sales using the 1986 editions of the same sources used to determine 1995 sales.
} 
Street Journal Index CD-ROM files. These searches of news stories revealed that many of firms for which I was unable to obtain 1995 sales and employment data had gone out of business. I did not include in the analysis the employment and sales of firms that had been acquired, unless the firm continued to be operated as a separate subsidiary through the end of 1995 . Another exception was cases where the purchase of the firm was an asset sale as part of a bankruptcy, in which case employment and sales were recorded as zero. In some cases, I was only able to determine a range in which sales fell. In these cases, I employed the mid-point of this range.

\section{Empirical Analysis}

Table 6 compares the growth of the Phase II awardees with the matching firms. The mean employment increase from the end of 1985 to the end of 1995 was greater for the awardees (a boost of 26 employees vs. 5), as was the sales increase ( $\$ 5$ million vs. $\$ 2$ million). For the mean SBIR awardee, this represented an $56 \%$ increase in employment and a $123 \%$ boost in sales (in inflationadjusted dollars). The table also presents various percentile rankings in order to demonstrate that the differences were not driven by a few outliers. At each reported percentile, the changes in employment and sales were more positive for the awardees. These differences were statistically significant in t-tests and Wilcoxon rank-sum tests.

Tables 7 and 8 examine the impact of SBIR awards in light of the concentration of venture capital financing. I undertook comparisons similar to those in Table 6, but with an additional complication: firms were divided by whether (i) their headquarters at the end of 1985 was located 
in a zip code with a private early-stage venture financing in the years 1983-1985 or (ii) their primary assignment was to a four-digit SIC class with such a financing. I determined whether any (and how many) early-stage financings occurred in each zip code and SIC class through the Venture Intelligence Database described above.

The differences between the SBIR awardees and the matching firms in the zip codes with one or more venture financings were pronounced. For instance, employment increased by 47 for these firms, as opposed to decreasing by 5 for the non-awardees The differences were much less pronounced elsewhere (employment rose by 13, as opposed to by 10). These differences were statistically significant only among the firms in regions with venture activity. For the average SBIR awardee in a zip code with venture activity—which had 57 employees and $\$ 3.9$ million in sales in 1985-employment over the next decade grew by $83 \%$ and inflation-adjusted sales by 169\%. These patterns are depicted in Figures 1 and 2. The first picture shows the number of seed and early-stage venture capital investments in each county in the continental U.S. between 1983 and 1985; the second depicts the mean employment growth of SBIR awardees in each county between 1985 and 1995."

\footnotetext{
${ }^{11}$ These patterns were also robust to the use of a third measure of firm success, the increase in public market value. For the subset of SBIR awardees and matching firms that were publicly traded sometime between January 1985 and December 1995, I examined the change in valuations over this interval. I determined these valuations through the databases of the Center for Research in Securities Prices and the several Moody's stock guides. The public market valuation of the 541 SBIR awardees increased by a total of $\$ 9.5$ billion in this period. (This is the sum of the increase in the market value of firms that were publicly traded at the beginning of the period and the valuation of formerly private firms that went public over these years.) The public market valuation of the 594 matching firms, on the other hand, only increased by a total of $\$ 2.6$ billion. The increase in the public market value of the average SBIR awardee was 19 times greater if the firm was located in a zip code with an early-stage venture financing in the years 1983-1985, a 
The analysis in Table 8, however, reveals few clear patterns. The differences between the growth of the SBIR awardees and the matching firms were similar, whether the companies were in an industry that received venture financing or not.

These patterns remained pronounced when I disaggregated the matching firms. If the positive performance of the SBIR Phase II awardees was due primarily to the selection of superior firms rather than the infusion of capital, we might expect the Phase I awardees to similarly display rapid growth. These firms, despite receiving much smaller awards, went through an exhaustive review process: only $12 \%$ of applicants were selected for these preliminary grants in the first three program years (U.S. General Accounting Office [1987b]). (In the Phase II selection process, 50\% of the applicants received awards.)

The growth of sales and employment was only slightly greater among the 294 firms that received SBIR Phase I awards than the 300 firms taken from the Corporate Technology Directory. For instance, the mean employment for the Phase I awardees increased by 6.2 jobs, while for the Directory firms, the increase was 4.2. (Recall that the increase in the Phase II awardees' employment was over 26 jobs.) The differences between the SBIR Phase II awardees that were significant in Tables 6 and 7 remained so when the Phase II awardees were only compared either to the Phase I awardees or to the Corporate Technology Directory firms.

difference significant at the five percent confidence level. There were no significant differences in the changes in public market valuations of SBIR Phase II awardees and non-awardees among those firms located in zip codes without early-stage venture activity. 
Tables 9 and 10 examine the growth of employment and sales in a regression framework. I used 1995 employment and sales as the dependent variables, and employed a variety of independent variables and specifications. The first two regressions in each table used an ordinary least squares (OLS) specification. Among the independent variables were 1985 employment or sales, a dummy variable indicating whether the firm received any Phase II awards in the first three SBIR funding cycles, measures of the extent of venture capital activity in the firm's zip code and SIC class, and interactions between the SBIR dummy variable and the venture capital activity measures. In the reported regressions, I measured the extent of venture capital activity in two ways: the number of early-stage financings in the zip code or SIC code, as well as dummy variables indicating whether there were any such financings.

I also report a variety of alternative specifications. First, because 1995 employment and sales could not be below zero, I used a Tobit specification, which corrected for censored data. (I also estimated Tobit regressions using the other sets of independent variables, which produced results similar to the reported OLS analyses.) Second, rather than using a single dummy variable to denote SBIR awardees, I disaggregated the number of SBIR awards. I employed separate variables for firms that received only one Phase II SBIR award in the first three cycles, two-to-four such awards, and so forth. Third, I added additional independent variables to the analysis. I was concerned that the results may have been shaped by some unobserved differences between the SBIR awardees and the matching firms. I hence controlled for each firm's age, whether it was 
venture-backed by the end of 1985, and the nature of its industry. Following Gompers [1995], I controlled for industry effects by using the characteristics of the average public firm in the same SIC class at the end of 1985 . I computed the ratios of market value to book value, tangible assets to total assets, and R\&D spending to sales for all firms with a primary assignment in Compustat to the same industry as a company in the sample. If there were fewer than four firms assigned to a fourdigit SIC code, I used all firms with a primary assignment to the same three-digit SIC code. I then computed the average of these ratios. In this way, I controlled for industry differences that may have affected the ability of firms to raise external financing through traditional sources. For instance, firms in industries characterized by mostly intangible assets may have found it difficult to arrange bank financing.

The results strongly supported the suggestions that the impact of SBIR awards was not uniform. The presence of a SBIR award alone had little impact on employment and sales. Rather, only the interactions between the SBIR indicator and the measures of venture activity in the zip code were consistently significant in the employment and sales regressions SBIR awards had a strongly positive impact on firms that were in areas simultaneously receiving venture financing, but no significant impact on other firms. This effect was robust across the different specifications. In some regressions, the coefficient on the interaction between the SBIR awardee dummy variable and the measures of venture activity in the region and industry was significantly negative. This suggested that the beneficial effect of SBIR awards was greatest if the firm was in an area attracting considerable venture investment, but not in a frequently financed industry. 
I examined the robustness of the regressions in several unreported analyses. The results were robust to the use of the total dollar volume of early-stage venture financings in the zip code and SIC class between 1983 and 1985, instead of the number of such awards. I alternatively employed the number of early-stage financings in the state and the two-digit SIC code as independent variables. These two alternative specifications weakened the significance of the results, but the coefficients on the interaction terms remained significant at conventional confidence levels. I re-estimated the equations only using the Phase II SBIR awardees and the Corporate Technology Directory matching firms, as well as only the Phase II and Phase I SBIR awardees. The smaller sample sizes led to reduced significance levels, but had little effect on the magnitudes or signs of the coefficients. The magnitude and significance of the coefficients changed little when I estimated systems of two equations, with the second equation examining the propensity of firms to win Phase II awards in the first three program cycles. Finally, rather than employing an OLS or Tobit specification, I estimated a two-stage Heckman regression. I first examined whether the firm survived and then the extent of its growth. The interaction terms remained strongly significant.

An alternative explanation for the superior growth of the SBIR awardees is that winners of SBIR awards were more likely to subsequently receive procurement contracts because they had cultivated relationships with politicians or federal program managers. To examine this possibility, I restricted the above analysis to the two agencies which made significant numbers of SBIR awards but were unlikely to undertake procurement contracts with awardees: the National Science Foundation and the Department of Health and Human Services (HHS). HHS's external 
research, and consequently their SBIR awards, overwhelmingly came from the National Institutes of Health. The gap between the firms that received Phase II awards from these agencies and those that only received Phase I awards was even greater than that in the sample as a whole. For instance, firms that received Phase II awards from NSF and HHS in the first three program cycles grew by 32.6 employees between 1985 and 1995; those that only received Phase I awards grew by 2.1 employees. $^{12}$

\section{Conclusions}

This paper examined the long-run impact of awards to new high-technology firms made through a major public venture capital initiative, the SBIR program. First, several rationales why these awards might or might not have had positive effects on firms were explored, as well as whether the impacts were likely to be stronger in regions and sectors that attracted substantial earlystage financing from venture capitalists I compared the growth of awardees to a set of matching firms. The SBIR awardees enjoyed substantially greater employment and sales growth, but these effects were confined to firms in areas that attracted significant venture financing.

\footnotetext{
${ }^{12}$ I also compared the awardees from HHS to matching firms specializing in biology and biochemistry that had received no SBIR awards, with similar results. Another alternative explanation for the superior growth of the SBIR awardees is that winners of SBIR awards were more likely to win subsequent SBIR awards. While this may have been true in the initial years of the program (e.g., U.S. General Accounting Office [1987b]), conversations with federal officials suggest that it has been much less of an issue in recent years. Not only were SBIR awards to firms that had receiving multiple previous grants more likely to be scrutinized by the GAO, resulting in a reluctance to make such grants, but the 1992 reauthorization of the SBIR program (Public Law 102-564) added additional criteria for the evaluation of SBIR applications of firms that had received awards in the past.
} 
I have already discussed some of the issues raised by alternative interpretations of the results. At least three additional questions can be raised concerning the analysis. One concern is whether political pressures will lead to a deterioration of the SBIR program's effectiveness over time. First, as discussed above, the percentage set-aside for SBIR awards has increased dramatically. This may be leading program managers to fund less promising firms. Second, the program has attracted congressional scrutiny due to the geographic concentration of its awards. Program managers to date have resisted these pressures: the share of funds going to firms in California or Massachusetts has remained constant at around $40 \%$. Because the awards appear to only have had a positive effect on firms in regions with significant venture financing, the political pressures towards geographic dispersion-were they to succeed in shifting the distribution of awards - might have a detrimental effect on program effectiveness ${ }^{13}$

A second concern about the results relates to whether the supply of private equity has adjusted to address any capital constraints. As discussed above, the pool of venture capital expanded during the 1980 s. The capital constraints that may have troubled small high-technology firms during the early 1980s, when these awards were made, may have vanished today. The

${ }^{13}$ The pathologies that can result from political pressures on government technology policies are discussed in Cohen and Noll [1991] and Romer [1993]. On the other hand, SBIR program managers in most agencies indicate that program quality has increased over time. They argue that this increase is due to the rising ratio of applicants to awards, and the growing ability of evaluators to discern the qualities that presage commercial success as well as scientific excellence. These observations are confirmed by the GAO, which has found [1985, 1987b, 1995] that in those agencies where a consistent scoring system has been used to rate SBIR applications, awardees' scores have risen steadily. In addition, the GAO has found [1985, 1987a] that several agencies were tardy in coming into compliance with SBA procedures as the program began. 
expansion of the private equity market may have obviated the need for such a program, and the long-run competitive advantage that SBIR awards confer today may be much lower. These questions about the changes in the effectiveness of the program over time will only be answerable in the future.

Another important unanswered question relates to the social benefits of the program. Numerous studies have suggested that, because of knowledge spillovers, social rates of return to privately funded $R \& D$ are often much higher than the private returns which the firms performing the research enjoy. This analysis has focused exclusively on private returns, as roughly measured through sales and employment growth. The differentials between the private and social benefits of the SBIR awards might be particularly large, because many of them involve very early-stage technologies (where spillovers to other firms may be more frequent) or those important to national defense. At the same time, the program's critics argue that the SBIR set-aside has led to a reduction in funding for academic research, which may have even greater social benefits [e.g., Mervis, 1996]. The program's impact on social welfare is an important, but difficult to resolve, issue.

The evidence presented here suggests that public initiatives to provide capital for new firms may have only a limited economic impact. This role, it appears, is much more as a complement to the venture capital organizations and other private institutions that assist new firms: the impact of the awards in regions without these private sector mechanisms was minimal. This raises questions 
about recently enacted programs (summarized in Table 1) that encourage public financing of and guarantees for venture funds that invest in economically disadvantaged areas.

At the same time, SBIR awards appear to have had a positive and substantial long-run impact on the firms in regions with considerable venture capital activity. In particular, awardees appear to have grown substantially faster-whether measured by sales or employment - than a matching set of firms. These results suggest that economists need to ask somewhat different questions about such public initiatives.

As discussed in footnote 2, a major focus of economic studies of federal technology programs has been the issue of "crowding out": has federal funding led to less private sector investment, particularly in $R \& D$, than would have occurred otherwise? It is not clear, however, that this is the proper question to be asking of programs that assist small, possibly capitalconstrained, companies. For many of these firms, a major concern of management is extending the amount of time until they need to seek refinancing or run out of capital..$^{14}$ Thus, it is not clear whether the pattern of small firms using public funds to extend the period before they need to seek refinancing, rather than using the funds to increase their rate of research funding, should be

\footnotetext{
${ }^{14}$ The ability of SBIR funds to give researchers additional time to prove the viability of a new technology was repeatedly emphasized in my interviews with awardees. More generally, the impact that concerns about running out of cash-colloquially known as "fume dates"-have on the management of new ventures is discussed in Sahlman [1990]. Gompers [1995] documents how venture capitalists adjust the amount of capital they provide and hence the amount of time until the firm needs to seek refinancing in response to uncertainty and informational asymmetries.
} 
considered problematic. While an assessment of the ultimate success of firms receiving public venture funding may not answer all the questions about these programs, this type of analysis is an important complement to studies of the short-run impact on R\&D spending.

Even if, as Wallsten [1996] argues, capital constraints are unimportant and firms simply substitute SBIR funding for their own expenditures, the funds provided by the program may still be important. One of the important benefits conferred by SBIR awards, participants argue, is the signal that they provide to potential investors and customers. ${ }^{15}$ Were SBIR awards purely an honorary designation, they might more readily be designated for explicitly political considerations. The presence of a substantial financial component - and the associated regulatory provisions that govern such awards - may limit these pressures, and insure that the awards are an effective signal of the quality of a firm's technology.

\footnotetext{
${ }^{15}$ As illustrations of this claim, several directories of high-technology firms denote companies that have won SBIR awards, and at least 103 press releases concerning SBIR awards were issued between August 1995 and July 1996.
} 


\section{References}

Barry, Christopher B., 1994, "New Directions in Research on Venture Capital Finance," Financial Management 23 (Autumn), 3-15.

Charles River Associates, 1976, An Analysis of Capital Market Imperfections Cambridge, Charles River Associates.

Clarke, Marianne K., 1987, State-Supported SBIR Programs and Related State Technology Programs, Washington, National Governors' Association.

Cohen, Linda R., and Roger G. Noll, 1991, The Technology Pork Barrel, Washington, Brookings Institution.

Colton, R.M., editor, 1982, Analyses of Five National Science Foundation Experiments to Stimulate Increased Technological Innovation in the Private Sector, Washington, National Science Foundation.

Corporate Technology Information Services, 1996, Corporate Technology Directory, Woburn, Massachusetts, Corporate Technology Information Services (and earlier years).

Devenow, Andrea, and Ivo Welch, 1996, "Rational Herding in Financial Economics," European Economic Review, 40, forthcoming.

Dun's Marketing Services, 1996, Million Dollar Directory, Parsippany, New Jersey, Dun's Marketing Services (and earlier years).

Eisenger, Peter, 1991, "The State of State Venture Capitalism," Economic Development Quarterly, 5 (February)64-76.

1993, "State Venture Capitalism, State Politics, and the World of High-Risk Investment," Economic Development Quarterly, 7 (May) 131-139.

Fenn, George W., Nellie Liang, and Stephen Prowse, 1995, The Economics of the Private Equity Market, Washington, Board of Govemors of the Federal Reserve System.

Fox, James W., 1996, "The Venture Capital Mirage: An Assessment of USAID Experience with Equity Investment," Unpublished working paper, Center for Development Information and Evaluation, U.S. Agency for International Development.

Freear, John, and William E. Wetzel, Jr., 1990, "Who Bankrolls High-Tech Entrepreneurs?," Journal of Business Venturing, 5, 77-89.

Gale Research, 1996, Ward's Business Directory of U.S. Private and Public Companies, Detroit, Gale Research (and earlier years).

Gompers, Paul A., 1995, "Optimal Investment, Monitoring, and the Staging of Venture Capital," Journal of Finance, $50,1461-1489$.

, and Josh Lerner, 1996a, "The Use of Covenants: An Analysis of Venture Partnership Agreements," Journal of Law and Economics, 39, forthcoming.

, and , 1996b, “The Valuation of Private Equity Investments," Unpublished working paper,

Harvard University. 
Good, Mary L., 1995, "Prepared Testimony before the Senate Commerce, Science and Transportation Committee, Subcommittee on Science, Technology and Space," (January 31), mimeo.

Griliches, Zvi, 1986, "Productivity, R\&D, and Basic Research at the Firm Level in the 1970's," American Economic Review, 76, 141-154.

Hall, Bronwyn, H., 1992, "Investment and Research and Development: Does the Source of Financing Matter?," Working Paper No. 92-194, Department of Economics, University of California at Berkeley.

Hao, Kenneth Y., and Adam B. Jaffe, 1993, "Effect of Liquidity on Firms' R\&D Spending," Economics of Innovation and New Technology, 2, 275-282.

Himmelberg, Charles P., and Bruce C. Petersen, 1994, "R\&D and Internal Finance: A Panel Study of Small Firms in High-Tech Industries," Review of Economics and Statistics, 76, 38-51.

Hubbard, R. Glenn, 1996, "Capital-Market Imperfections and Investment," Journal of Economic Literature, forthcoming.

Irwin, Douglas A., and Peter J. Klenow, 1994, "High Tech R\&D Subsidies: Estimating the Effects of Sematech," National Bureau of Economic Research Working Paper No. 4974.

Krugman, Paul R., 1991, Geography and Trade, Cambridge, MIT Press, 1991.

Lerner, Josh, 1995, "Venture Capitalists and the Oversight of Private Firms," Journal of Finance, 50, 301-318.

Levy, David M., and Nestor E. Terleckyj, 1983, "Effects of Government R\&D on Private R\&D Investment and Productivity: A Macroeconomic Analysis," Bell Journal of Economics, 14, 551-561.

Mansfield, Edwin, John Rapoport, Anthony Romeo, Samuel Wagner, and George Beardsley, 1977, "Social and Private Rates of Return from Industrial Innovations," Quarterly Journal of Economics, 91, 221-240.

Mervis, Jeffrey D., 1996, “A \$1 Billion Tax on R\&D Funds," Science, 272, 942-944.

Myers, Sumner, Robert L. Stem, and Marcia L. Rorke, 1983, A Study of the Small Business Innovation Research Program, Lake Forest, Illinois, Mohawk Research Corporation.

National Register Publishing Company, 1996, Directory of Leading Private Companies, Including Corporate Affiliations, Wilmette, National Register Publishing Company.

Noone, Charles M., and Stanley M. Rubel, 1970, SBICs: Pioneers in Organized Venture Capital, Chicago, Capital Publishing Company.

Organisation for Economic Co-operation and Development, 1982, Innovation in Small and Medium Firms: Background Reports, Washington, OECD Publications and Information Center.

Price, Waterhouse, 1985, Survey of Small High-Tech Businesses Shows Federal SBIR Awards Spurring Job Growth, Commercial Sales, Washington, Small Business High Technology Institute.

Private Equity Analyst, 1996, "Fund Raising in '96 Shatters Record, Soaring 29\% to Reach \$27 Billion," Private Equity Analyst, 6 (January), 1, 29-31. 
Romer, Paul M., 1993, "Implementing a National Technology Strategy with Self-Organizing Investment Boards," Brookings Papers on Economic Activity: Microeconomics, 345-390.

Sahlman, William A., 1990, "The Structure and Governance of Venture-Capital Organizations," Journal of Financial Economics, 27, 473-521. , and Howard Stevenson, 1986, "Capital Market Myopia," Journal of Business Venturing, 1, 7-30.

Saxenian, Annalee, 1994, Regional Advantage: Culture and Competition in Silicon Valley and Route 128, Cambridge, Harvard University Press.

Sparkman, John, 1958, "Introduction," in U.S. Congress, Senate, Small Business Committee, Small Business Investment Act of 1958, Washington, Government Printing Office.

U.S. Congressional Budget Office, 1985, Federal Financial Support for High-Technology Industries, Washington, CongressionalBudget Office.

U.S. Department of Housing and Urban Development, Model Cities Administration, 1970, Model Cities: Continued Planning and Evaluation, Washington, U.S. Department of Housing and Urban Development.

U.S. General Accounting Office, 1981, Consistent Criteria are Needed to Assess Small Business Innovation Activitie, Washington, General Accounting Office.

1985, Implementing the Small Business Innovation Development Act - The First Two Years, Washington, General Accounting Office.

1987a, Federal Research: Small Business Innovation Research Participants Give Program High Marks, Washington, General Accounting Office.

1987b, Federal Research: Effectiveness of Small Business Innovation Research Program Procedures, Washington, General Accounting Office.

1989, Federal Research: Assessment of Small Business Innovation Research Programs, Washington, General Accounting Office.

1992, Federal Research: Small Business Innovation Research Shows Success But Can Be Strengthened, Washington, General Accounting Office.

1995, Federal Research: Interim Report on the Small Business Innovation Research Program, Washington, General Accounting Office.

U.S. Office of Technology Assessment, 1984, Technology, Innovation and Regional Economic Development, Washington, Office of Technology Assessment.

U.S. Small Business Administration, 1986, Listing of SBIR Awardees for FY 1985, Washington, Government Printing Office (and earlier years).

, 1994, Small Business Innovation Development Act: Tenth-Year Results, Washington, Government Printing Office (and earlier years).

,1996, http://www.sbaonline.sba.gov/Research_And_Development. 
Venture Economics, 1996, "Special Report: Rose-Colored Asset Class," Venture Capital Journal, 36 (July), 32-34 (and earlier years).

Vincenti, Lisa, 1996, "Trio Preps Unusual Effort to Raise Capital for Early-Stage Funds," Venture Capital Journal, 36 (February), 10.

Wallsten, Scott J., 1996, "The Small Business Innovation Research Program: Encouraging Technological Innovation and Commercializationin Small Firms?," Unpublished working paper, Stanford University.

Wupperfeld, Udo, 1992, The Role of Various Types of German Investment Companies for the Financing of New Technology-Based Firms, Karlsruhe, Franhofer-Institut fur Systemtechnik and Innovationsforschung. 


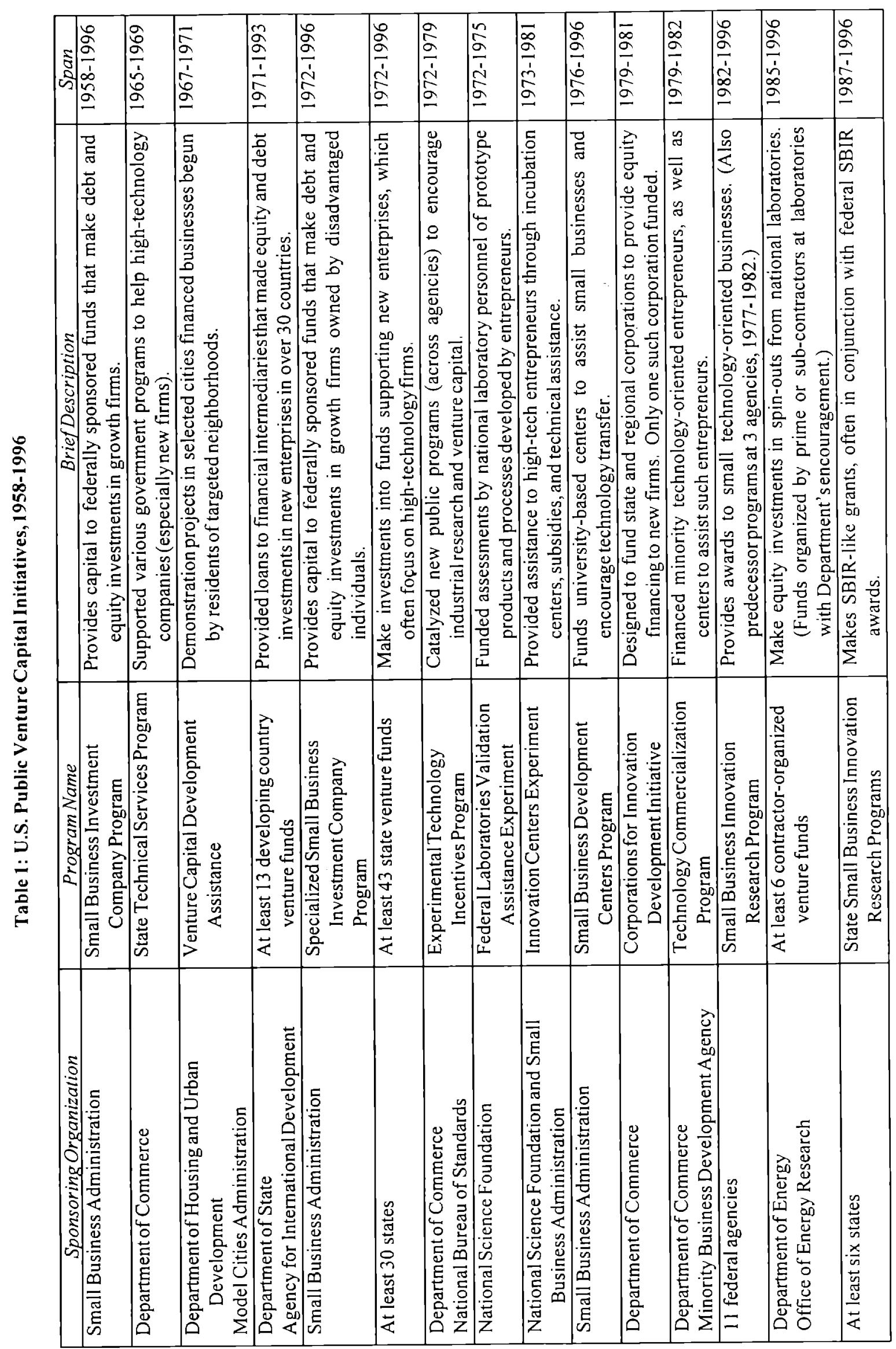




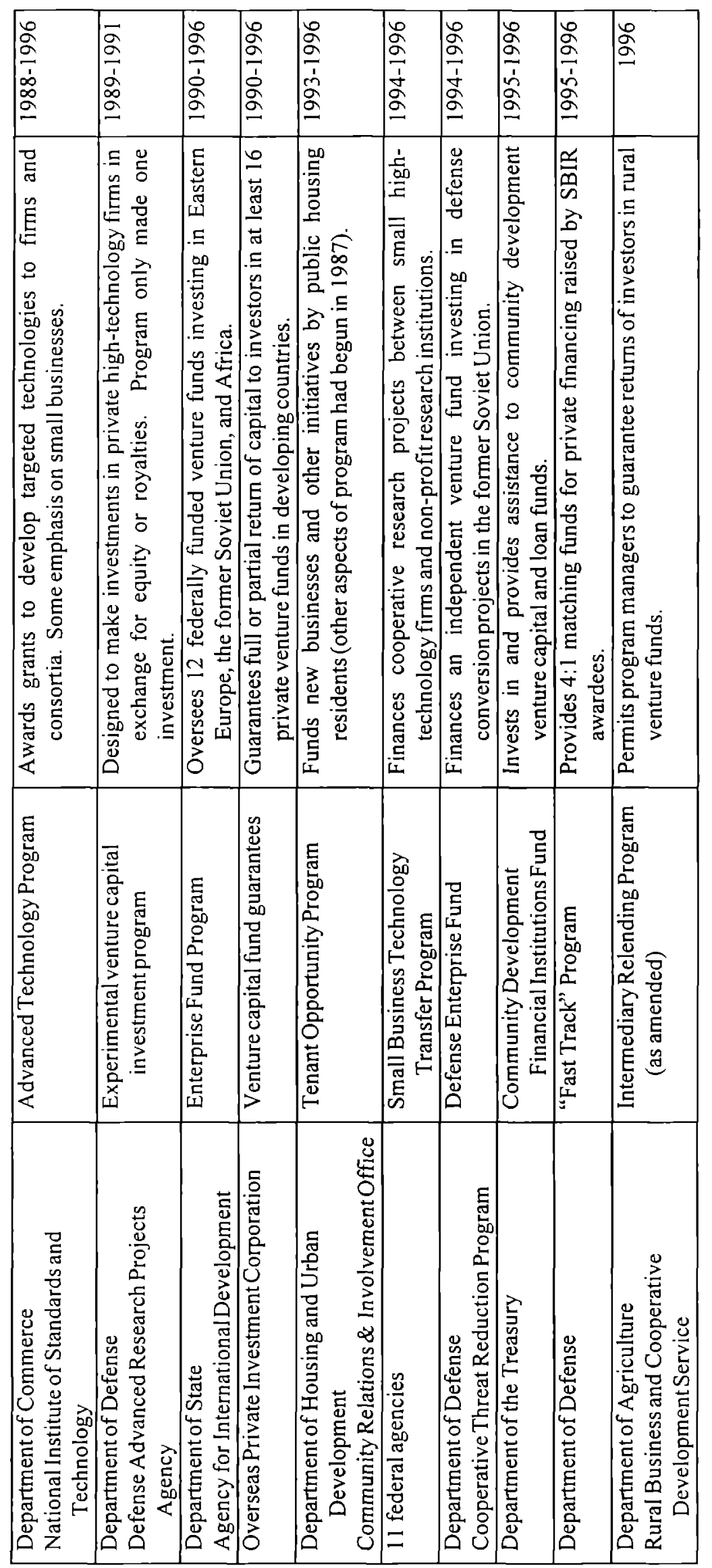

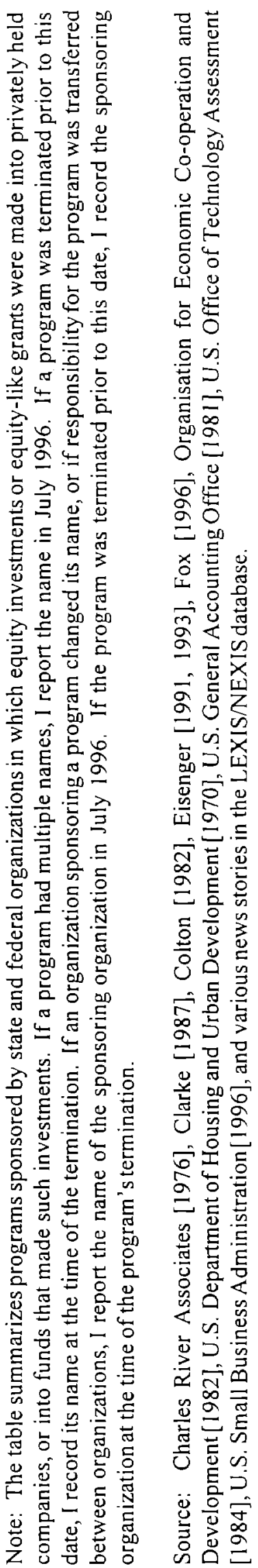


Table 2: Volume of Venture Capital Activity

\begin{tabular}{|c|c|c|c|c|}
\hline \multirow[b]{2}{*}{ Year } & \multirow{2}{*}{$\begin{array}{l}\text { Venture Capital } \\
\text { Pool at Year End }\end{array}$} & \multicolumn{3}{|c|}{ Early-Stage Investments by Venture Funds } \\
\hline & & \multicolumn{2}{|c|}{ Sof Financings $\quad I$} & Number of Financings \\
\hline 1977 & 1554 & \multicolumn{3}{|c|}{474} \\
\hline 1978 & 1996 & \multicolumn{3}{|c|}{520} \\
\hline 1979 & 2056 & \multicolumn{3}{|c|}{755} \\
\hline 1980 & 3049 & \multicolumn{3}{|c|}{802} \\
\hline 1981 & 4452 & \multicolumn{2}{|r|}{806} & 227 \\
\hline 1982 & 6391 & \multicolumn{2}{|r|}{813} & 343 \\
\hline 1983 & 11796 & \multicolumn{2}{|r|}{1707} & 413 \\
\hline 1984 & 16640 & \multicolumn{2}{|r|}{1689} & 568 \\
\hline 1985 & 20880 & \multicolumn{2}{|r|}{1194} & 529 \\
\hline 1986 & 25186 & \multicolumn{2}{|r|}{1478} & 716 \\
\hline 1987 & 30645 & \multicolumn{2}{|r|}{1440} & 796 \\
\hline 1988 & 34024 & \multicolumn{2}{|r|}{1272} & 674 \\
\hline 1989 & 37379 & \multicolumn{2}{|r|}{1119} & 623 \\
\hline 1990 & 38292 & \multicolumn{2}{|r|}{705} & 571 \\
\hline 1991 & 38148 & \multicolumn{2}{|r|}{458} & 335 \\
\hline 1992 & 38910 & \multicolumn{2}{|r|}{646} & 435 \\
\hline 1993 & 36401 & \multicolumn{2}{|r|}{765} & 368 \\
\hline 1994 & 36066 & \multicolumn{2}{|r|}{1005} & 499 \\
\hline 1995 & 36362 & \multicolumn{2}{|c|}{1438} & 611 \\
\hline \multicolumn{5}{|c|}{ Leading States, Early-Stage Venture Financing, 1983-1985 } \\
\hline State & & \multicolumn{2}{|c|}{$\$$ of Financings \% of Total } & \# of Financings \\
\hline \multicolumn{2}{|l|}{ California } & 2089 & 45.5 & 770 \\
\hline Massachusett & & 643 & 14.0 & 310 \\
\hline Texas & & 299 & 6.5 & 130 \\
\hline New York & & 153 & 3.3 & 65 \\
\hline New Jersey & & 136 & 3.0 & 97 \\
\hline & Leading Industries, & y-Stage Venture F & lancing, 198 & $33-1985$ \\
\hline Industry (SIC & Code) & $\$$ of Financings & $\%$ of Total & I of Financings \\
\hline Prepackaged & Software (7372) & 570 & 12.4 & 347 \\
\hline Semiconduct & $\operatorname{rrs}(3674)$ & 402 & 8.8 & 91 \\
\hline Computer Per & ipherals (3577) & 328 & 7.1 & 130 \\
\hline Telephone A & oparatus (3661) & 317 & 6.9 & 107 \\
\hline Electronic Co & mputers $(3571)$ & 254 & 5.5 & 75 \\
\hline
\end{tabular}

Note: The table provides an overview of investment activity by U.S. venture capital organizations. The first panel indicates the total size of the venture capital pool and the amount of early-stage investment. The venture capital pool is defined as the capital raised by all venture funds that had a first closing within the past ten years. The second and third panels display the amount of early-stage investments in the period 1983-1985, disaggregated by the leading states and industries. All amount figures are in millions of 1994 dollars. No data are available on the number of early-stage investments prior to 1981 .

Source: Private Equity Analyst [1996], Venture Economics [1996], and unpublished Venture Economics databases. 
Table 3: Volume of SBIR Awards

\begin{tabular}{lrrr}
\hline & \multicolumn{2}{c}{ SBIR Awards } & Size of External \\
Year & \$ Amount & \# of Phase II Awards & R\&D Set-Aside \\
1983 & 64 & 0 & $0.2 \%$ \\
1984 & 150 & 388 & $0.6 \%$ \\
1985 & 266 & 407 & $1.0 \%$ \\
1986 & 388 & 564 & $1.25 \%$ \\
1987 & 442 & 768 & $1.25 \%$ \\
1988 & 472 & 711 & $1.25 \%$ \\
1989 & 502 & 749 & $1.25 \%$ \\
1990 & 513 & 837 & $1.25 \%$ \\
1991 & 518 & 788 & $1.25 \%$ \\
1992 & 530 & 916 & $1.25 \%$ \\
1993 & 664 & 950 & $1.5 \%$ \\
1994 & 694 & 961 & $1.5 \%$ \\
1995 & 847 & & $2.0 \%$ \\
1996 & & & $2.0 \%$ \\
1997 & & & $2.5 \%$ \\
\hline
\end{tabular}

Note: The table provides an overview of the SBIR program. It indicates the amount of awards, the number of such awards, and the share of external R\&D spending that all agencies spending more than $\$ 100$ million on external $R \& D$ were required to set aside for the program. The Department of Defense was allowed an extra year to reach the $1.25 \%$ target, and consequently had lower set-aside levels between 1983 and 1986. All amount figures are in millions of 1994 dollars.

Source: U.S. Small Business Administration [1994, 1996]. 
Table 4: Construction of Sample of SBIR Phase II Awardees and Matching Firms

General Accounting Office Survey:

Sample Size

Number of Firms

Respondents to 1986 General Accounting Office Survey

Respondents to 1988 General Accounting Office Survey

Respondents to Either General Accounting Office Survey

Of Respondents to Either General Accounting Office Survey:

Received One or More Phase Il Awards in First Three Program Cycles

Did Not Receive Phase II Award in First Three Program Cycles

Matching Firms Selected Through 1986 Corporate Technology Directory

Final Sample:

Phase II Awardees from Survey 
Table 5: Comparison of SBIR Phase II Awardees and Matching Firms

\begin{tabular}{|c|c|c|c|c|}
\hline Variable & Mean & Standard Deviation & Minimum & Maximum \\
\hline \multicolumn{5}{|l|}{541 SBIR Phase II Awardees } \\
\hline Year Founded & 1977.5 & 6.9 & 1935 & 1985 \\
\hline Received Venture Financing (thru 1985)? & 0.10 & 0.30 & 0 & 1 \\
\hline 1985 Employment & 46.6 & 85.8 & 0 & 600 \\
\hline 1985 Sales & 3.0 & 6.3 & 0.1 & 65.0 \\
\hline Publicly Traded in January $1985 ?$ & 0.03 & 0.17 & 0 & 1 \\
\hline \# of Phase II Awards in First 3 Cycles & 2.8 & 3.5 & 1 & 30 \\
\hline Located in California? & 0.21 & 0.41 & 0 & 1 \\
\hline Located in Massachusetts? & 0.14 & 0.34 & 0 & 1 \\
\hline \multicolumn{5}{|c|}{ \# of Early-Stage Venture Financings, 1983-1985, in ... } \\
\hline State & 230.0 & 293.3 & 0 & 770 \\
\hline Zip Code & 3.2 & 8.1 & 0 & 46 \\
\hline SIC Code & 2.2 & 7.2 & 0 & 47 \\
\hline \multicolumn{5}{|l|}{594 Matching Firms } \\
\hline Year Founded & 1976.2 & 10.5 & 1899 & 1985 \\
\hline Received Venture Financing (thru 1985)? & 0.07 & 0.26 & 0 & 1 \\
\hline 1985 Employment & 37.0 & 72.0 & 0 & 650 \\
\hline 1985 Sales & 3.4 & 6.8 & 0.1 & 64.0 \\
\hline Publicly Traded in January $1985 ?$ & 0.04 & 0.20 & 0 & 1 \\
\hline \# of Phase II Awards in First 3 Cycles & 0 & 0 & 0 & 0 \\
\hline Located in California? & 0.18 & 0.39 & 0 & I \\
\hline Located in Massachusetts? & 0.08 & 0.28 & 0 & 1 \\
\hline \multicolumn{5}{|c|}{ \# of Early-Stage Venture Financings, 1983-1985, in ... } \\
\hline State & 203.6 & 278.4 & $\mathbf{0}$ & 770 \\
\hline Zip Code & 1.8 & 5.6 & 0 & 46 \\
\hline SIC Code & 2.6 & 9.3 & 0 & 95 \\
\hline
\end{tabular}

Note: The table provides summary statistics on the 541 firms that received SBIR Phase II awards in the first three program cycles and the 594 matching firms in the sample. All sales figures are in millions of current dollars. 
Table 6: Growth of SBIR Phase II Awardees and Matching Firms

\begin{tabular}{|c|c|c|c|}
\hline & SBIR Phase II Awardees & Matching Firms & p-Value from Comparison \\
\hline \multicolumn{4}{|c|}{ Comparisonof Means [t-tests] } \\
\hline \multicolumn{4}{|c|}{ Change in Employment, 1985-1995 } \\
\hline Mean & 26.20 & 5.22 & \multirow[t]{3}{*}{0.057} \\
\hline Standard Error & 16.32 & 4.78 & \\
\hline Observations & 499 & 561 & \\
\hline \multicolumn{4}{|c|}{ Change in Sales, 1985-1995 } \\
\hline Mean & 5.05 & 1.76 & \multirow[t]{3}{*}{0.019} \\
\hline Standard Error & 1.30 & 0.63 & \\
\hline Observations & 493 & 551 & \\
\hline \multicolumn{4}{|c|}{ Comparison of Distributions [Wilcoxon tests] } \\
\hline \multicolumn{4}{|c|}{ Change in Employment, 1985-1995 } \\
\hline $90^{\text {th }}$ Percentile & 66 & 31 & \multirow[t]{5}{*}{0.002} \\
\hline $75^{\text {th }}$ Percentile & 10 & 5 & \\
\hline Median & -1 & -2 & \\
\hline $25^{\text {th }}$ Percentile & -8 & -10 & \\
\hline $10^{\text {th }}$ Percentile & -45 & -50 & \\
\hline \multicolumn{4}{|c|}{ Change in Sales, 1985-1995 } \\
\hline $90^{\text {th }}$ Percentile & 9.0 & 5.5 & \multirow[t]{5}{*}{0.000} \\
\hline $75^{\text {th }}$ Percentile & 2.0 & 0.8 & \\
\hline Median & 0.1 & -0.1 & \\
\hline $25^{\text {th }}$ Percentile & -0.3 & -0.5 & \\
\hline $10^{\text {th }}$ Percentile & -3.0 & -5.8 & \\
\hline
\end{tabular}

Note: The table summarizes the change in the employment and sales of the 541 firms that received SBIR Phase II awards in the first three program cycles and the 594 matching firms in the sample. All sales figures are in millions of current dollars. 
Table 7: Growth of SBIR Phase II Awardees and Matching Firms, by Location

Firms Located in Zip Code with an Early-Stage Venture Financing, 1983-1985

Change in Employment, 1985-1995

$\begin{array}{lrr}\text { Mean } & 47.43 & -4.61 \\ \text { Standard Error } & 22.99 & 8.37 \\ \text { Observations } & 190 & 181 \\ \text { Change in Sales, 1985-1995 } & & \\ \text { Mean } & 9.03 & 1.23 \\ \text { Standard Error } & 3.11 & 0.99 \\ \text { Observations } & 189 & 175\end{array}$

Firms Located in Zip Code without an Early-Stage Venture Financing, 1983-1985 Change in Employment, 1985-1995

\begin{tabular}{lrrr} 
Mean & 13.14 & 9.90 & 0.752 \\
Standard Error & 8.80 & 5.86 & 380 \\
Observations & 309 & & 0.627 \\
Change in Sales, $1985-1995$ & & 2.02 & 0.81 \\
Mean & 2.58 & 376 & \\
Standard Error & 0.81 & 304 & \\
Observations & & & \\
\hline
\end{tabular}

Note: The table summarizes the change in the employment and sales of the 541 firms that received SBIR Phase II awards in the first three program cycles and the 594 matching firms in the sample. Firms are divided by whether their headquarters in 1985 was in a zip code with one or more seed or early-stage venture financings between 1983 and 1985. All sales figures are in millions of current dollars. 
Table 8: Growth of SBIR Phase II Awardees and Matching Firms, by Industry

$$
\text { SBIR Phase II Awardees }
$$

Firms Located in SIC Code with an Early-Stage Venture Financing, 1983-1985

Change in Employment, 1985-1995

Mean

Standard Error

Observations

Change in Sales, 1985-1995

Mean

Standard Error

Observations
28.45

12.40

324

5.04

1.51

319
12.83

7.64

310

\subsection{5}

1.04

306

Firms Located in SIC Code without an Early-Stage Venture Financing, 1983-1985 Change in Employment, 1985-1995

Mean

Standard Error

Observations

Change in Sales, 1985-1995

Mean

Standard Error

Observations
22.02

18.46

175

5.07

2.42

174
$-4.05$

5.04

251

1.04

0.57

245
0.116

0.061

Note: The table summarizes the change in the employment and sales of the 541 firms that received SBIR Phase II awards in the first three program cycles and the 594 matching firms in the sample. Firms are divided by whether their primary industry assignment in 1985 was to a SIC code with one or more seed or early-stage venture financings between 1983 and 1985. All sales figures are in millions of current dollars. 


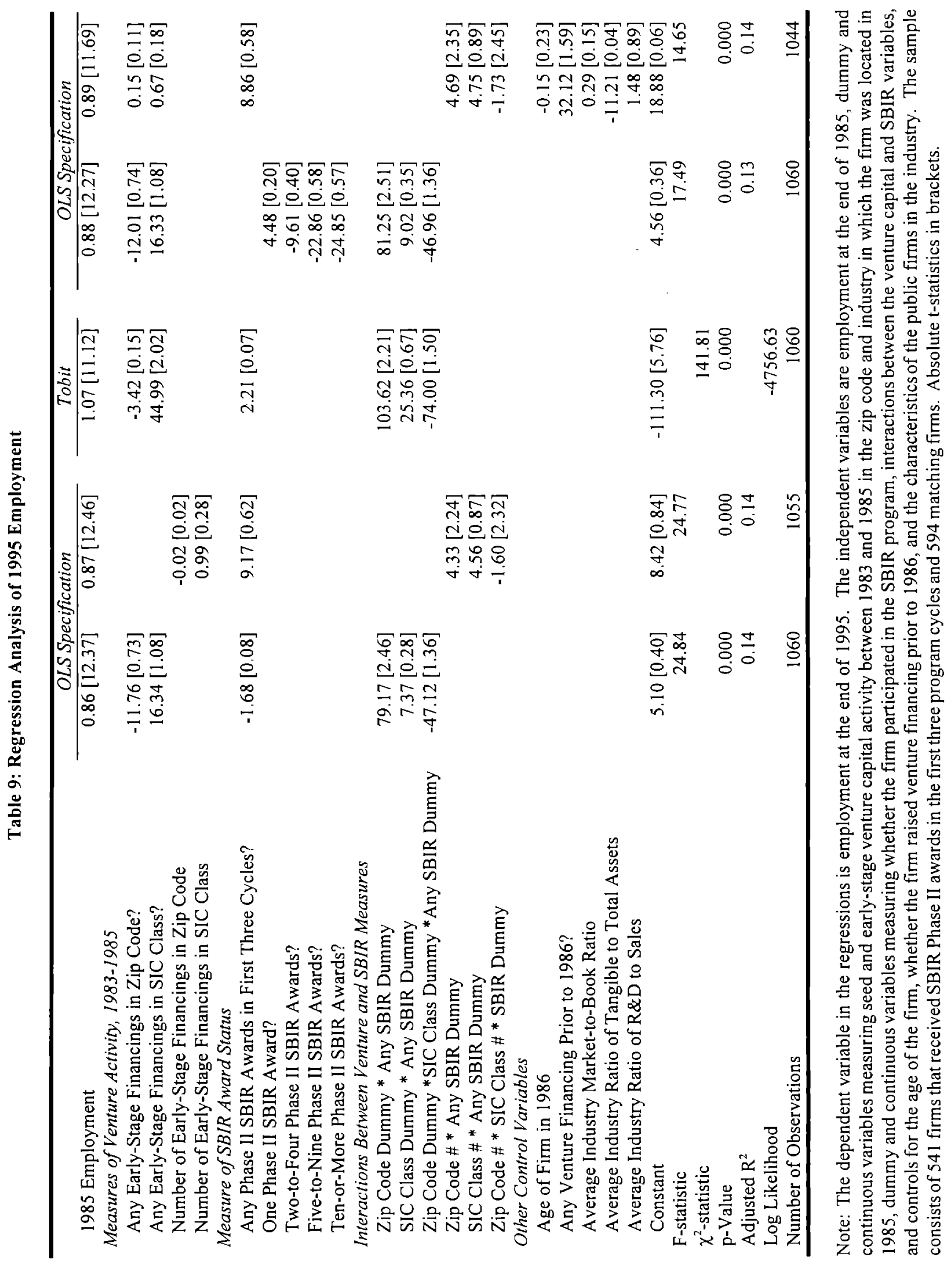




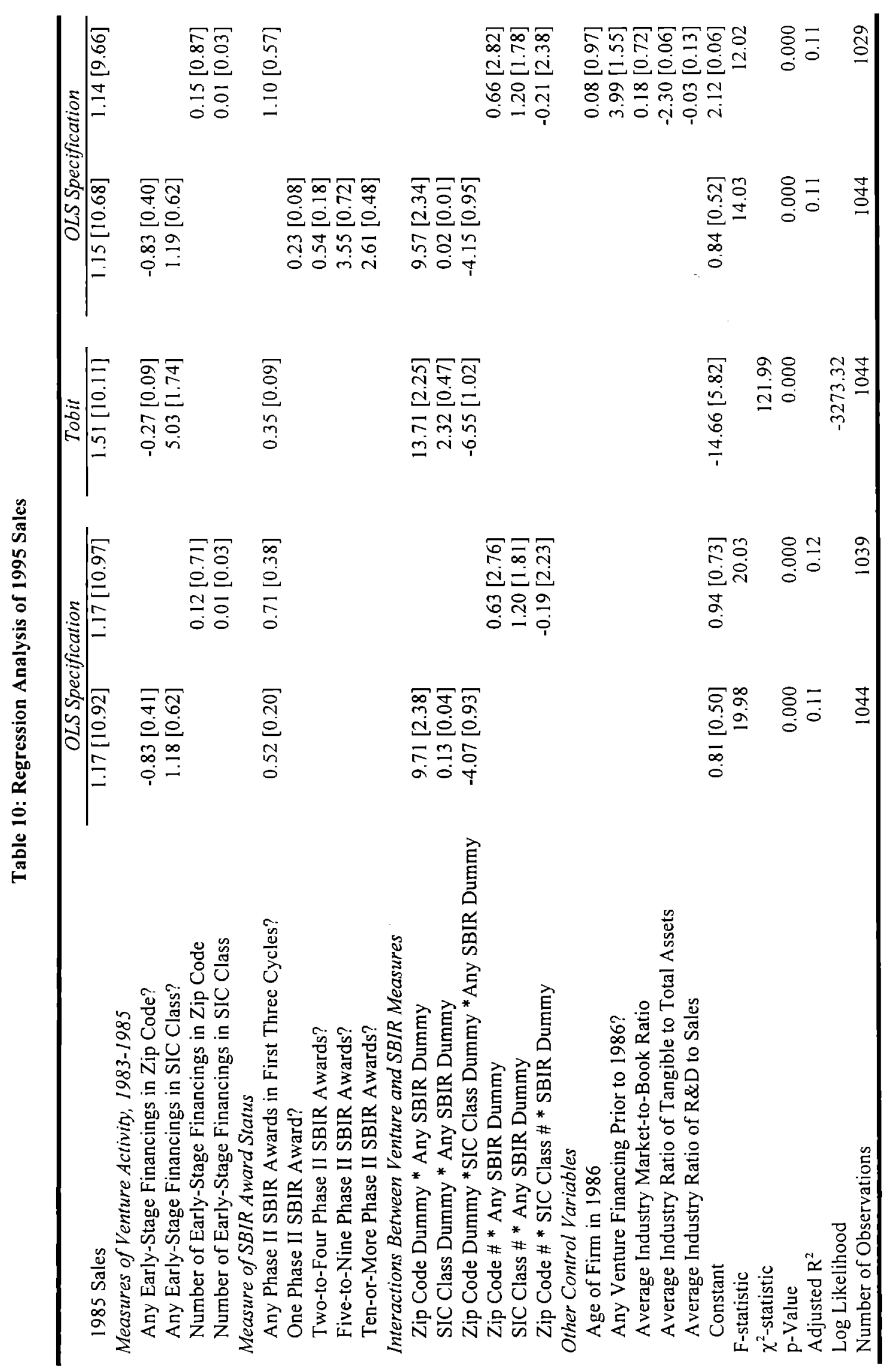

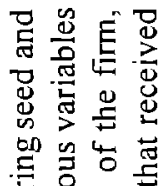

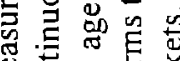

㔛焉

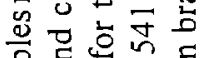

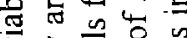

굴은

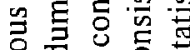

记

表尔 응

8 응

몽

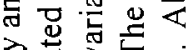

E 응

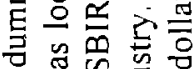

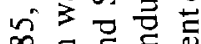
田西声 到西焉

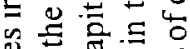

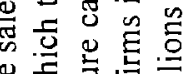

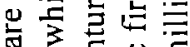

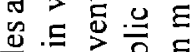
公司。

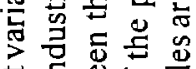

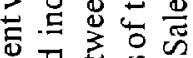

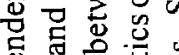

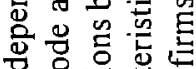
엉응 원 况通氙 는

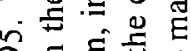
合. 톯 $\therefore$ 语

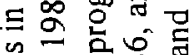
岁 드용 品 흥 ज可 흥

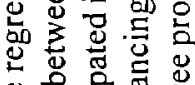
․ㅡㅇ 它昰息 . 跣 을 롱 要的 त 웡용 동

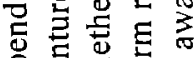
용 10

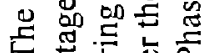

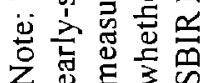



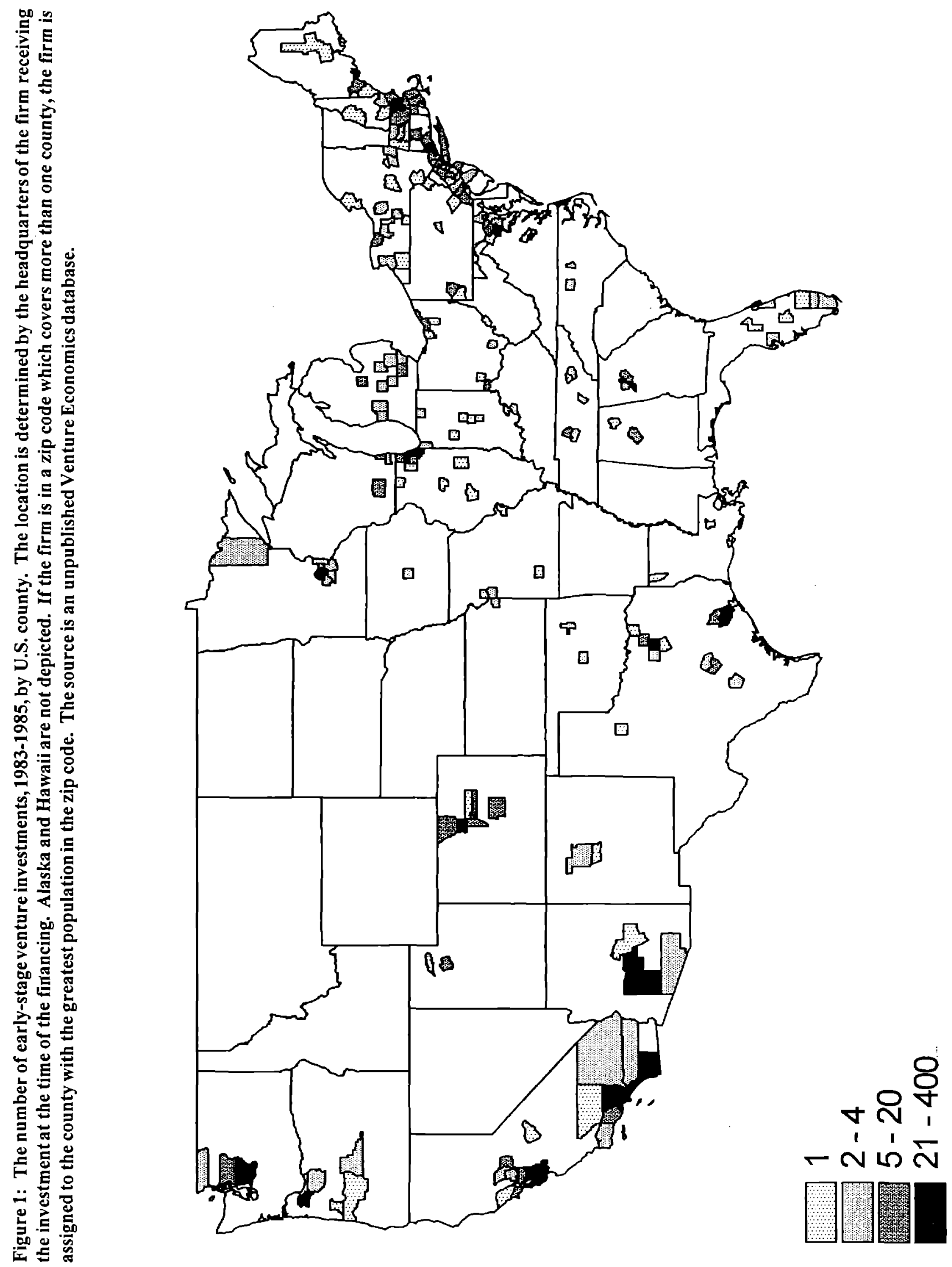

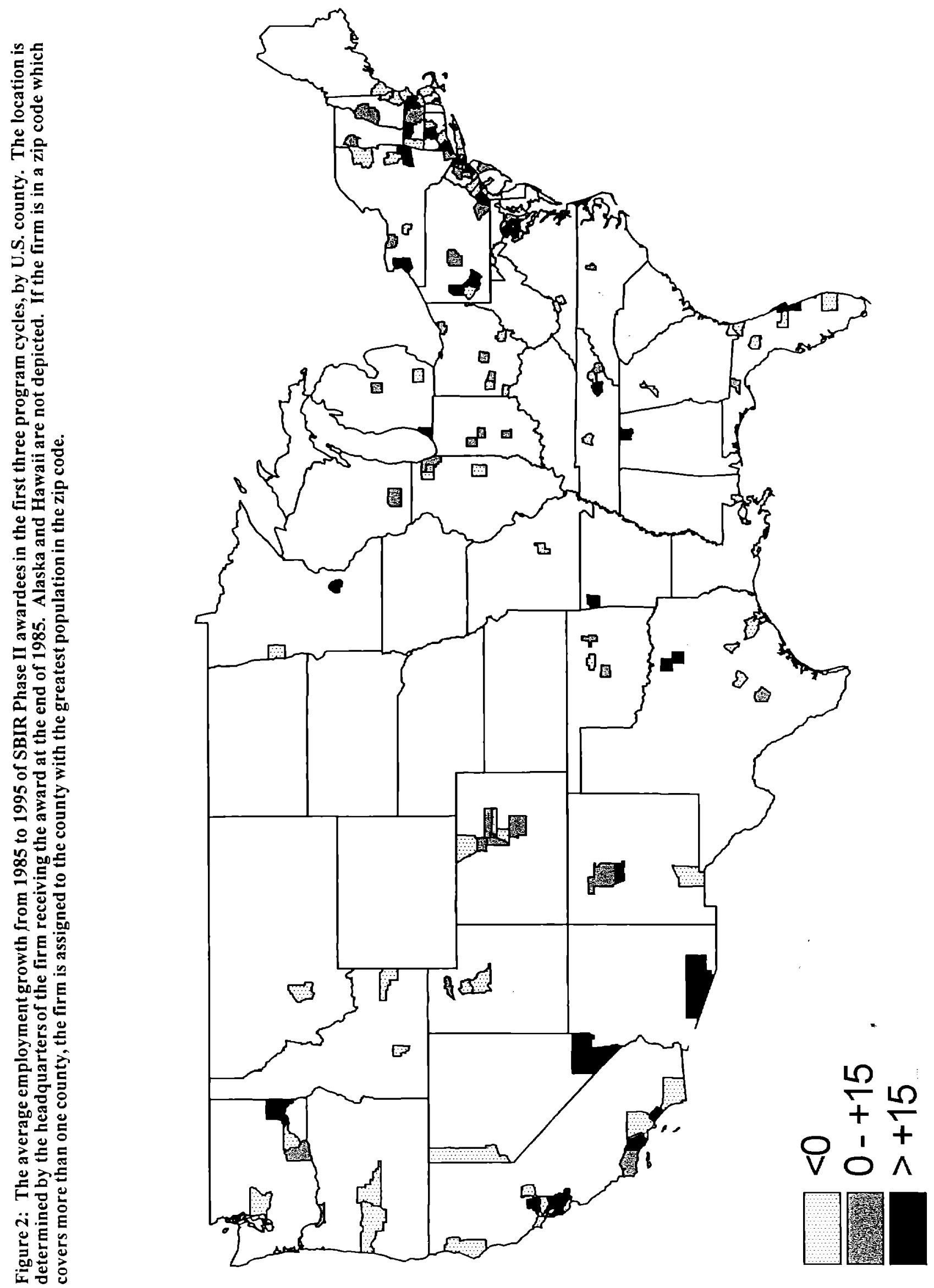